but unfortunately, in some cases they were injected in the muscularis propria or subserosa; occasionally part of the fat was injected into the lumen. The homologous fat was obtained from the abdominal cavity. Part was heated to 361 to $365^{\circ} \mathrm{C}$ for 30 minutes. In both groups each animal received $0.05 \mathrm{cc}$. in the wall of fundus and $0.05 \mathrm{cc}$. in the wall of antrum, on the ventral face of the stomach.

The term IAL is used to designate the mucosa with atypical proliferation in situ and/or invasion of glands into the submucosa (Fig. 1). The aspect of the adenomatous cells is normal but they are generally endowed with great secretory activity (Fig. 2). In a certain number of cases the glands undergo a cystic change. No one of the animals showed, histologically, aspects of malignancy in these lesions. It was observed, in all the animals, foreign-body granuloma at the injection site as a reaction to exogenous substances. Table 1 summarizes the experimental data.

Table 1. Gastric lesions in the guinea pig induced following intramura injection of heated fat

\begin{tabular}{|c|c|c|c|c|c|c|}
\hline \multirow[b]{2}{*}{ Treatment } & \multirow[b]{2}{*}{ No. $\left.{ }^{a}\right)$} & \multirow[b]{2}{*}{ Days $\left.^{b}\right)$} & \multicolumn{4}{|c|}{ No. of animals with IAL } \\
\hline & & & Fundus*) & $\left.F+A^{c}\right)$ & $\begin{array}{l}\text { Ant- } \\
\text { rum }\end{array}$ & $\begin{array}{c}\text { Inc. } \\
\%\end{array}$ \\
\hline Non hea & 9 & $17-18$ & 0 & 0 & 0 & 0 \\
\hline Non heated fat & 7 & 90 & 0 & 0 & 0 & 0 \\
\hline Heated fat & 9 & $16-26$ & 3 & $1(26)$ & $1(26)$ & $55 \cdot 5$ \\
\hline Heated fat & 11 & 90 & $3(90)$ & 0 & 0 & $27 \cdot 2$ \\
\hline
\end{tabular}

a) Number of animals; b) Duration of experiment (days); c) Fundus and antrum; d) Incidence (\%)

*) In parenthesis are shown the periods of time in days, between the intramural injection of fat and the necropsy.

It can be seen that no lesions were found in the group of animals receiving non heated fat, in contrast to what was observed in the group with heated fat. It is evident that the gastric lesions induced by heated fat is a very early reaction, being visible already 24 days after treatment. The surprising difference between the percentages of the groups of 16 to 26 and 90 days would be explained by the following facts: a) The absorption of the fat, especially by the foreign-body granuloma cells; b) the variable amount of material, involuntarily injected into the gastric wall.

Institute of Experimental Medicine, National Health Service, Santiago, and Institute of Biology, Austral University, Valdivia

Eingegangen am 17. November 1958

$$
\text { R. S. D. ZALDIVAR* }
$$

*) Present address: Institute of Biology, Austral University. Casilla 567, Valdivia (Chile)

1) Roffo, A. H.: Bull. du Cancer 28, 556 (1939). - 2) Peacock, P. R., S. BeCK and J. G. Chalmers: J. Nat. Cancer Inst. 13, 931 (1953).

\section{Über den Natrium- und Kaliumgehalt des Walker-Carcinoms der Ratte}

Ein wesentliches Merkmal der lebenden Zelle ist ihre Făhigkeit, bestimmte Konzentrationsunterschiede gegenüber dem umgebenden Milieu zu entwickeln und aufrechtzuerhalten. So ist der Kaliumgehalt der tierischen Zelle um ein Vielfaches größer, der Natriumgehalt dagegen erheblich geringer als derjenige des extracellulären Raumes. Zahlreiche Untersuchungen der letzten Jahre haben gezeigt, daB die Erhaltung von Konzentrationsgradienten für Natrium und Kalium zwischen dem intra- und extracellulären Raum Energie aus dem respiratorischen ${ }^{1}$, , ${ }^{2}$ ) oder glykolytischen ${ }^{2}$, , ${ }^{3}$ ) Stoffwechsel erfordert; bei der Übertragung der Energie auf die Transportmechanismen spielen die energiereichen Phosphatverbindungen eine entscheidende Rolle ${ }^{4}$, ${ }^{5}$ ). Werden aus irgendeinem Grunde die Stoffwechselprozesse in der Zelle beeinträchtigt, so ist eine der unmittelbaren Folgen die Reduktion der Ionengradienten; bei vollständigem Erlöschen der Zelltätigkeit tritt schließlich ein Konzentrationsausgleich zwischen dem intra- und extracellulären Raum ein.

Ein interessantes Beispiel für die Abhängigkeit der Elektrolytverteilung vom Funktionszustand des Gewebes sei im folgenden kurz beschrieben. Die Untersuchungen wurden an Walker-Carcinomen der Ratte durchgefülurt. Nach Exstirpation wurden die Tumoren mit Hilfe einer Rasierklinge nach der Methode von Deutsch ${ }^{6}$ ) in etwa 0,4 bis $0,8 \mathrm{~mm}$ dünne
Scheiben geschnitten und die so erhaltenen Gewebeschnitte für 24 Std in $0,1 \mathrm{~N} \mathrm{HNO}_{3}$ stehen gelassen \%. Nach entsprechender Verdünnung erfolgte die Bestimmung von $\mathrm{Na}$ trium und Kalium mit einem Flammenphotometer-Zusatz des Beckman-Spektralphotometers DU.

Der Kaliumgehalt der Walker-Carcinome zeigte ebenso wie der Natriumgehalt erhebliche Schwankungen. Auch im selben Tumor waren die Unterschiede innerhalb weniger Millimeter recht beträchtlich. Eine genauere Betrachtung der Werte ergab, daß bei hohem Kaliumgehalt der dazugehörige Natriumwert niedrig war und umgekehrt, d. h., daß Natriumund Kaliumgehalt sich reziprok verhielten (Fig. 1). Die Summe beider Kationen (Mittelwert $156 \mu$-Äquiv./g Frischgewicht) war innerhalb bestimmter Grenzen gleich. Dieses Ergebnis läßt sich folgendermaßen interpretieren. Das relativ schnell wachsende Walker-Carcinom der Ratte durchläuft in kurzer Zeit alle bekannten Stadien der Geschwulstentwicklung von der beginnenden malignen Entartung über verschiedene Degenerationsformen bis zum nekrotischen Gewebszellzerfall. Solche Carcinome sind daher nicht nur vom histologischen, sondern auch vom stoffwechsel - physiologischen Standpunkt aus betrachtet uneinheitlich, und es liegt der Schluß nahe, daß sich die Zellen innerhalb eines Tumors in verschiedenen Funktionszuständen befinden. Diese unterschiedliche Stoffwechselaktivität der Carcinomzellen findet w. a. ihren Ausdruck in dem oben beschriebenen Verhalten der Elektrolyte; da-

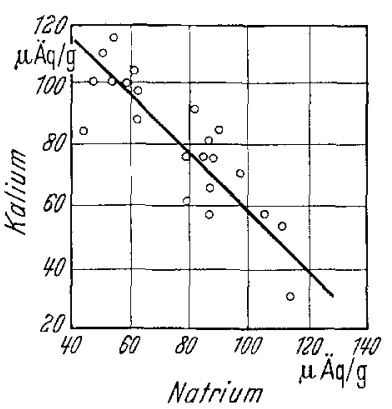

Fig. 1. Abhängigkeit des Kaliumgehaltes vom Natriumgehalt in Walker-Carcinomen der Ratte bei weisen ein niedriger

Kalium- und hoher Natriumgehalt des Gewebes auf eine bereits eingeschränkte Stoffwechselleistung hin, während ein hoher Kalium- und niedriger Natriumgehalt für eine noch ausreichende Energielieferung sprechen. So erscheint es berechtigt, in dem Verhalten der Elektrolyte einen Indikator der Funktionstüchtigkeit des Gewebes zu sehen.

Herrn Dr. H. K. Parchwitz danke ich für die Überlassung von Walker-Carcinomen, Herrn Dr. H. W. SchreıBER für einige Hinweise und der Deutschen Forschungsgemeinschaft für eine Sachbeihilfe.

Chemische Abteilung der Chirurgischen Universitätsklinik und Poliklinik (Direktor: Prof. Dr. A. Gürgemans), BonnVenusberg

Eingegangen am 4. November 1958

H. BREUER

1) Krebs, H. A., L. V. Eggleston u. C. Terner: Biochemic. J. 48, 530 (1951). —2) Breuer, H., u. R. Whittam: J. Physiology 135, 213 (1957). - 3) Harris, J. E.: J. Biol. Chem. 141, 579 (1941). 4) Caldwell, P. C., u. R. D. Keynes: J. Physiology 137, 12 P (1957). - 5) Breuer H., u. R. Whittam: J. Physiology 144, $20 \mathrm{P}$ (1958). - $\left.{ }^{6}\right)$ Deutsch, W.: J. Physiology 87, 56 P (1936).

\section{Adsorption of Poliomyelitis Virus on Cholesterol}

In a recent publication YoungNeR and NOLI ${ }^{1}$ ) described the adsorption of a number of viruses on cholesterol columns. Only poliovirus (Parker strain, Type I) was not adsorbed. We should like to report a somewhat similar experiment in which evidence for adsorption of poliovirus on cholesterol was obtained. Our work was patterned after the experiments of Toomex ${ }^{2}$ ) who, in 1937, showed that when cholesterol and a suspension of poliovirus were tumbled in a ball mill for 12 hours and then centrifuged, the aqueous phase was not infectious for monkeys.

We used an MEF-1 strain of Type 11 poliovirus, which is adapted to hamster brain and can be titrated in mice intracerebrally. This strain was used because it was not feasible to assay cholesterol adsorbed poliovirus in tissue culture since the turbidity due to the insolubility of the sterol made observation of cells impossible.

A shallow suspension of cholesterol $(1 \mathrm{~g})$ was added to $6 \mathrm{ml}$ of a $1 \%$ suspension of poliovirus and the resulting mixture was agitated by a magnetic stirrer bar which covered the entire bottom of the vessel. After 18 hours at $0^{\circ} \mathrm{C}$ the suspension was centrifuged in a plastic tube, the infranatant withdrawn by puncturing a hole in the bottom and the 